\title{
Spindle Cell Rhabdomyosarcoma
}

National Cancer Institute

\section{Source}

National Cancer Institute. Spindle Cell Rhabdomyosarcoma. NCI Thesaurus. Code C6519.

An uncommon variant of rhabdomyosarcoma characterized by the presence of whorls of spindle cells forming a storiform pattern. In children it usually arises in the paratesticular region. In adults it usually arises from the deep soft tissues in the head and neck. 